$\log$ E 0.2ステップが安定性がありデータ点も多く得ら れた。今後，Alステップの形状等について検討する。

483. われわれが行っている Sensitometry の紹介と測 定精度について

熊本大学医学部附属病院中放

$\bigcirc$ 守部伸幸・洞田貫誠志

勝田 昇・肥合康弘

熊本大学医療技術短期大学部 東田善治

〔目的〕一般診断用 X 線装置を用いて, 精度の良い特 性曲線を求めるには，いろいろな困難と煩雑さをともな う。われわれは，インテンシスケール法による特性曲線 を求める場合について, 幾つかの改良点を加え, 精度, 再現性，および時間的にも効率の良い方法を行っている ので報告した。

〔方法抢よび結果】特別の真空パックカセッテおよび， そのスライダと, 各装置間とのインターフェイスを試作 $し, X$ 線制御器の制御およびX 線出力のチェック, カセ ッテの移動，また記録等を自動的にマイコンで行うこと によって，迅速，かつ，精度，再現性ともに目的に添う 特性曲線が得られるようになった。

\section{4. 増感紙一フィルム系の感度の測定}

熊本大学医療短大 ○東田善治 熊大病院中放

洞田貫誠志・守部伸幸

勝田 昇 ・肥合康弘

広島大学歯学部 小寺吉衛

〔目的〕この研究の目的は，わが国にて使われている 増感紙一フィルム系の絶対感度, および相対感度を精度 よく測定することである。

〔方法〕測定方法は，BRHレポートに準じているが， Task 1 と Task 2 にわけて行っている. Task 1 では, 絶対感度の測定を行い， 9 種類の blue 系と， 9 種類の green 系の測定を行った。測定に用いる線質は, BRH canonical beam と ANSI chest beam である。

〔結果〕 各増感紙一フィルムの絶対感度の測定精度を, 数\%以内で求めることができた.

485. 二つの施設における増感紙一フィルムの MTF の 再現性について

熊本大学医学部附属病院中放

○肥合康弘・洞田貫誠志 守部伸幸・勝田 昇

熊本大学医療技術短期大学部 東田善治

同一試料の MTF 測定值に 2 つ施設間でどれだけの 再現性があるかということを見るために，当施設とシ力
ゴ大学で求められた MTF の比較を行った。方法として は，シカゴ大学で作成されたスリット像および，センシ トメトリックストリップを標準試料として MTF を測定 し，また当施設においてもスリット像を作成し，MTFを 測定するという2 段階に分けた比較を行った。

結果としては，標準試料を用いた方で，最も差が大き い所で0.021 MTF JNITE の差, すべての過程を当施設 で行った場合でも最大 0.0130 差におさまっており，良い 再現性が得られていると思われる。

\section{座長集約}

演題476は，管電圧と撮影条件の関係を散乱線，グリッ ド，被写体の性状など因子を含め求めている，n值と臨 床上のラチチュード，相対感度と係数による方法との比 較など末消化な面があるが, 有意な発表である。この分 野は，放射線技師の専門領域で画像と同等の重要な問題 である，諸因子を整理し，理論的，臨床的に再検討を行 い撮影条件論として体系づける必要があろう。

演題4840実験系は，一般に採用上困難を伴う。したが って信頼に足りるデータの提供を希望する。シカゴ大, BRH と同様に，物理特性を系統的に測定したいとする 意欲を何より高く評価する，演題479，485は，共に相対 的精度を求めているが，特に数値を公表された点に感謝 する。同様に写真特性も微妙な差異は, 特性曲線で不明 確な場合があり, 数值の発表を期待したい.なお , PDS-15 の改良点は詳細にふれていないが，同機で測定される場 合，資料と意見を求め参考にされるとよい。

演題477の夕イムスケール法は, 異論のあるところであ る.しかし，デー夕は自らの目的に役立つことが第一， 各法の特性を知りデータを活用すればよい，今後も問題 意識を抱き研究されるよう希望する，演題478，481に， 祐延（大阪大）は，長短所，誤差の処理，評価法を問う た。若干問題が残るとしたが結果には自信を示した。数 式化を試みる場合, 適応性, 特性曲線と階調曲線の関係 を比較検討する必要がある，いずれにしても，手処理と の差異はどの位生じるのか, 知りたい点ではある. 演題 4800 万法は, 昨年私が鉛ガラス法へと発展させたもので ある，今回，計らずも有用性を述べていただき感謝する。 アテニュエイタの透過率は, キャリア係数から算出すれ ば理論上の裏付ができると考える.演題 $482 に$ 関して過去 多数の報告がある。目的と使い方を誤らなければ実用上 簡便で有用な方法である. 大塚（山口大）は，管電圧と の関係を問うた。散乱体を用いる場合, 他の因子を含み 材質と形状，照射野そして線質などが，同条件でなけれ ば相互比較ができない. したがって，方法論より諸条件 
の規格化が急務である。演題483に対し，吉田（岡山大） は, 入射空，フィルム装着法と駆動方式を尋ねた。同様 な計画をされる場合は，是非見学されるよう希望する。

さて，気がついた点にふれたい。凧藤（池袋保）が， density の意味を (485), 柴田（新小倉）は，現像温度な ど実験条件の明記を指摘した。単位などグラフに関係す る数値は明確にし, 温度, 処理時間, 薬剤名, 線質など 基本条件は必ず記入すべきである。また，“はずである” など，あいまいな表現は避けてもらいたく，結果は自信 をもって発表されるようお願いする。

大塚（山口大）は，シカゴ大の特性曲線用試料に濃度 ムラを指摘，485と小寺 (広島大) は，中央部を測定，平 均值を求めるとした，文献など参考資料は，あくまでも 参考である，各自が確認すべきで参考資料の鵜吞みをし てはならない，他方，資料を求める場合，とかく考え方 とか，ソフトなどに敬意が払われない、金銭とは言わな いが何らかの配慮は必要である。また，他人を介してで はなく，直接本人に連絡すべきでこれは研究する者の礼 儀である。

最近，センシトメトリーは，方法に関心がもたれてい るが，目的，実用上などは論じられることが少ない。い ささか本末転倒の観がある，各法とも長短所があり，使 用目的，施設事情を考えないで，一法にとらわれるのは 愚かである。そして精度も，誤差の範囲と許容值の関係 を明確にして論じなけ机ば意味がない，おわりに，進行 上の不手際を深くお詫びする。

\section{イメージングカメラ}

座長 花山正行（阪大病院）

486. イメージングカメラにおけるテストパターンの必 要性

\author{
大阪府立病院○三原一博 \\ 放射線診断科 \\ 松田 猛・安部勝人
}

イメージングカメラの性能を評価する場合，CT装置 でスキャンした画像を用いて評価する方法や，パターン ジェネレータを用いて評価する方法等がいくつか報告さ れている，前者は，CT 装置の性能も含んだ方法となる し，後者の場合には，デジタル情報がフィルム上にどの ような濃度で出力されるかも同時に知りたい場合には， 充分とはいえない，また，イメージングカメラの性能評 価は，力メラを最良の状態に調整した上でなされるべき であると考える。今回われわ机は，力メラの性能評価と 画像調整の 2 面から検討を加え，9種類のテストパ夕ー
ンを発表した。これがけっして充分とはいえないが，テ ストパターンを規格化させる方向で検討を加えて頂きた W.

\section{7. 輝度計によるマルチカメラの評価}

厚生中央病院放射線科

○北村善明・西沢睦夫

前回の総会に引き続き，マルチカメラの評価を，輝度 計を用いて行った。今回は, CRT上のグレースケールを 直接測定することを試みるため，輝度計の受光部を小さ くした，受光空の大きさは, 直径 $3.5 \mathrm{~mm}$ である.このよ うな輝度計を使用することにより，CRTの輝度の再現 性，むらについて，より細かく検討することができた。 画像の評価は, 最終的には写真によって行われるが CRT の輝度の変化が，直接画質に影響するため, CRT の安定 が要求される。その評価は，フィルム一現像系を含まな い方法で行われるべきで，その意味では，今回われわれ が行った輝度計による評価は，大変有意義であると思わ れる。

\section{8. オートロック塔載型イメージングシステムにおけ} る使用と問題点

\section{浜松医科大学附属病院放射線部 \\ ○坂本真次・望月公二・杉江義男 竹田浩康・小川満男・金子昌生}

総合画像診断において,CRT 画像のハードコピー化が 多様化しつつある，現在，当院に扔いて，オートロック モニター搭載型イメージングカメラを使用し，各種画像 信号を数筒所の撮影場所から制御し，自現機直結で処理 している，本装置の使用経験として，種々の映像を 1 台 のイメージャで処理が行われ，省力化が可能となった。 また，初期故障も特になく安定した画像が得られている。 今後の課題としては，イメージングカメラにバッファー を追加することにより各種デー夕を同時に転送し，また， 優先順位を自動的に検知して効率良く処理を行うことに より，さらに省力化が期待できると思われる。

489. マルチフォーマットカメラの歪みの検討

奈良県立医科大学附属病院中央放射線部

○福神 敏・越智 保

宇山茂樹・水野吉将

奈良県立医科大学ガンセンター診療部

吉峰 正・弓場 忍 多田誠一・才田寿一

CT システムの記録系としてのマルチフォーマットカ メラの役割は，非常に重要である。しかし，内蔵されて いるレンズや, CRT, フィルムの諸特性により，コント 